\title{
Penguasaan technological pedagogical content knowledge calon guru Pendidikan Pancasila dan Kewarganegaraan
}

\author{
Imam Fitri Rahmadi a, ${ }^{*}$ \\ a Program Studi PPKn, Fakultas Keguruan dan Ilmu Pendidikan, Universitas Pamulang, Tangerang \\ Selatan, Indonesia \\ 1 imamrahmadi@unpam.ac.id* \\ *korespondensi penulis
}

\begin{tabular}{ll}
\hline \multicolumn{2}{l}{ Informasi Artikel } \\
\hline Sejarah artikel & \\
Diterima & $: 26-07-2018$ \\
Revisi & $: 01-10-2019$ \\
Dipublikasikan & $: 31-10-2019$ \\
\hline
\end{tabular}

\begin{abstract}
ABSTRAK
Analisis Technological Pedagogical Content Knowledge (TPACK) perlu dilakukan dalam rangka memahami tingkat pengetahuan guru untuk dapat mengintegrasikan teknologi pada pembelajaran abad 21. Studi ini dilakukan untuk mendapatkan profil tingkat penguasaan TPACK calon guru Pendidikan Pancasila dan Kewarganegaraan yang sedang menempuh pendidikan Strata 1 di Program Studi PPKn Fakultas Keguruan dan Ilmu Pendidikan (FKIP) Universitas Pamulang. Studi menggunakan metode self-report measure dalam bentuk survei. Secara keseluruhan, tingkat penguasaan TPACK calon guru PPKn termasuk dalam kategori baik. Namun, penguasaan pada technological knowledge, content knowledge dan technological pedagogical content knowledge memiliki total nilai rata-rata yang lebih rendah. Perlu diperhatikan setiap butir pernyataan yang memiliki nilai rata-rata lebih rendah daripada total nilai rata-rata pada setiap domain pengetahuan. Setiap lembaga pendidikan tenaga kependidikan perlu melakukan analisis TPACK supaya mengetahui apakah calon guru yang sedang dididik sudah memiliki pengetahuan yang dibutuhkan untuk dapat mengajar sesuai dengan tuntutan dan karakteristik pembelajaran abad 21 .
\end{abstract}

\section{Kata kunci:}

Integrasi Teknologi

Technological Pedagogical

Content Knowledge (TPACK)

Pendidikan Pancasila dan

Kewarganegaraan (PPKn)
Keywords:

Technology integration

Technological Pedagogical

Content Knowledge (TPACK)

Civic education

\begin{abstract}
Analyzing Technological Pedagogical Content Knowledge (TPACK) is needed to understand teachers' knowledge in term of integrating technology in 21st-century learning. This study to explore TPACK confidence of preservice civic education teachers at the Department of Civic Education, Faculty of Teacher Training And Education, Universitas Pamulang. The study used a self-report-measure method in the form of a survey. Overall, the TPACK confidence of preservice civic education teachers in a good category. However, the confidences in technological knowledge, content knowledge, and technological pedagogical content knowledge, have a lower average total score. It should noticed regarding statement items that have a lower average convictions than the technical average rating at each knowledge domain. Teacher education institute needs conducting a TPACK analysis to find out whether preservice teachers who are educated already have the appropriate teaching knowledge for demands and characteristics of 21 stcentury learning.
\end{abstract}

\section{Copyright (C) 2019 Imam Fitri Rahmadi}

\section{Pendahuluan}

Mengajar merupakan aktivitas kompleks yang membutuhkan berbagai pengetahuan dan keterampilan khusus. Aktivitas mengajar melibatkan aspek kualitas personal dan kompetensi (Haider \& Jalal, 2018; Meijer, Korthagen, \& Vasalos, 2009; Srinivasan et al., 2011; Walsh et al., 2018) yang apabila terus dilakukan dapat menjadi passion (Celik, 2017) dan profession (Sakuma, 2018). Teori 
lama mengatakan agar dapat mengajar dengan baik, seorang guru harus memiliki pengetahuan tentang konten dan pengetahuan tentang cara mengajar atau yang biasa disebut dengan pengetahuan pedagogik serta pengetahuan hasil perpaduan keduanya yang disebut sebagai Pedagogical Content Knowledge (PCK) (Shulman, 1986).

Namun seiring dengan perkembangan teknologi, muncul teori baru yang berpendapat bahwa supaya dapat mengajar dengan baik, selain pengetahuan tentang konten dan pengetahuan pedagogik, seorang guru juga harus memiliki pengetahuan tentang teknologi dan pengetahuan hasil perpaduan dari ketiga pengetahuan tersebut (Mishra \& Koehler, 2006). Hasil perpaduan antara pengetahuan konten, pedagogik dan teknologi yang dimaksud adalah Technological Content Knowledge (TCK), Technological Pedagogical Knowledge (TPK) dan Technological Pedagogical Content Knowledge (TPACK).

Selain sebagai salah satu pengetahuan baru, TPACK telah menjadi sebuah framework atau kerangka kerja (Koehler \& Mishra, 2008). TPACK framework memperkenalkan hubungan dan kompleksitas antara ketiga pengetahuan dasar (konten, pedagogik, dan teknologi) yang menghasilkan empat pengetahuan baru. TPACK framework dapat digunakan untuk menganalisis dan memahmi tingkat pengetahuan guru untuk dapat mengintegrasikan teknologi dalam pembelajaran (Cox \& Graham, 2009; Koehler, Mishra, \& Cain, 2009, 2013). Berikut ini gambar dari TPACK framework.

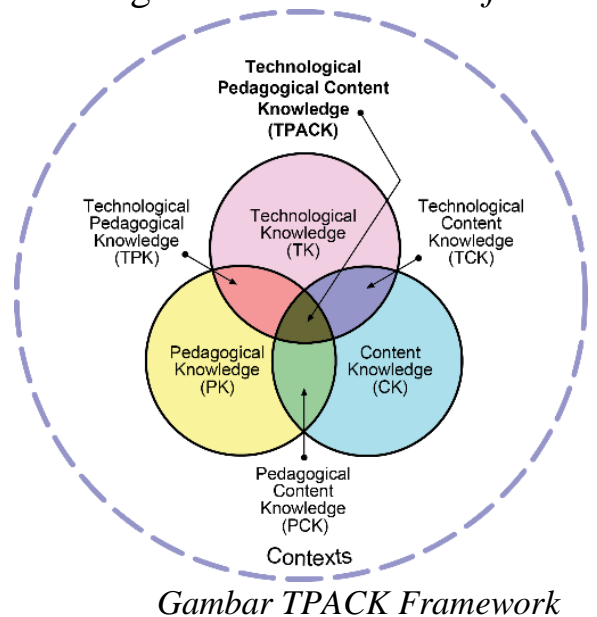

(Koehler \& Mishra, 2008)
Sesuai yang terlihat pada gambar di atas secara keseluruhan terdapat tujuh domain pengetahuan pada TPACK framework yang meliputi 1) Content Knowledge (CK); 2) Pedagogical Knowledge (PK); 3) Technological Knowledge (TK); 4) Pedagogical Content Knowledge (PCK); 5) Technological Content Knowledge (TCK); 6) Technological Pedagogical Knowledge (TPK); dan 7) Technological Pedagogical Content Knowledge (TPACK). Elaborasi terhadap setiap domain pengetahuan dijelaskan pada bagian hasil dan pembahasan.

Mengajar dengan mengintegrasikan teknologi merupakan tuntutan pembelajaran abad 21. Pembelajaran pada abad 21, memainkan secara aktif berbagai instrumen teknologi sebagai alat, proses maupun sumber (Partnership for 21st Century Learning, 2015). Proses dan lingkungan belajar harus memungkinkan akses yang setara terhadap alat, teknologi dan sumber belajar yang berkualitas. Hasil pembelajaran diarahkan untuk membekali siswa supaya dapat menjadi warga negara yang baik, yang dapat mengevaluasi, membuat dan menggunakan informasi, media dan teknologi dengan tepat dan efektif. Maka, dalam konteks pembelajaran abad 21 sangat penting bagi guru untuk menguasai TPACK (Kereluik, Mishra, Fahnoe, \& Terry, 2013).

Analisis TPACK pada calon guru maupun guru telah dilakukan di berbagai negara dengan salah satunya melihat pada program studi atau konten tertentu. Khususnya pada calon guru atau dalam kebanyakan penelitian lebih banyak menggunakan istilah preservice teachers, analisis TPACK telah dilakukan pada calon guru Bahasa Inggris (Baser, Kopcha, \& Ozden, 2016), ekonomi (Raman, 2014), Ilmu Pengetahuan Alam - IPA (Canbazoglu Bilici, Guzey, \& Yamak, 2016; Jang \& Tsai, 2012; Maeng, Mulvey, Smetana, \& Bell, 2013), matematika (Cuhadar, 2018; Jang \& Tsai, 2012), dan Ilmu Pengetahuan Sosial - IPS (Cuhadar, 2018). Serta masih banyak studi tentang analisis TPACK pada calon guru secara umum dengan tidak melihat pada Prodi atau konten tertentu. 
Studi tentang TPACK sudah mulai populer di Indonesia. Beberapa studi analisis TPACK pernah dilakukan pada calon guru Matematika (Listiawan \& Baskoro, 2015), biologi (Agustina, Putri, Sundari, \& Ardani, 2016; Agustina, Yusron, \& Muyassarah, 2018; Dhawati \& Hariyatmi, 2017; Sukaesih, Ridlo, \& Saptono, 2017), dan Fisika (Sholihah, Yuliati, \& Wartono, 2016). Semua studi yang pernah dilakukan berada pada bidang keilmuan IPA dan belum ditemukan studi analisis TPACK pada calon guru pada bidang keilmuan IPS. Maka dari itu, studi analisis TPACK pada calon guru Pendidikan Pancasila dan Kewarganegaraan (PPKn) ini sebagai salah satu bidang keilmuan IPS perlu dilakukan untuk melengkapi beberapa studi sebelumnya.

Studi ini dilakukan untuk mendapatkan profil TPACK calon guru PPKn yang diharapkan dapat bermanfaat bagi berbagai pihak yang berkepentingan dalam mempersiapkan guru masa depan Indonesia. Pihak yang berkepentingan yang dituju, khususnya adalah para pemangku kepentingan pada Lembaga Pendidikan Tenaga Kependidikan (LPTK) sebagai lembaga penyelenggara program pendidikan bagi calon guru profesional. Studi berusaha menjawab satu pertanyaan yakni bagaimana tingkat penguasaan TPACK calon guru PPKn yang sedang menempuh pendidikan Strata 1 (S1) di Prodi PPKn Fakultas Keguruan dan Ilmu Pendidikan (FKIP) Universitas Pamulang?

\section{Metode}

Setidaknya terdapat lima metode yang biasa digunakan untuk menganalisis TPACK, meliputi self-report measure, open-ended questionnaire, performance assessment, interview, observation (Abbitt, 2011; Koehler, Shin, \& Mishra, 2012). Studi ini dilakukan menggunakan metode self-report measure dalam bentuk survei. Metode tersebut dipilih karena sesuai dengan konteks studi dan merupakan metode yang paling banyak digunakan oleh para peneliti untuk menganalisis TPACK (Chai, Koh, \& Tsai, 2016; Mouza, 2016).
Sebuah kuesioner khusus untuk menganalisis TPACK calon guru PPKN telah dikembangkan dengan mengadaptasi dari Schmidt, Thompson, Koehler, \& Shin (2009) dan Sahin (2011) sebagai instrumen pengumpulan data survei. Secara keseluruhan kuesioner terdiri dari 57 butir penyataan yang meliputi ke-7 sub-domain TPACK. Rincian sebaran butir pernyataan yaitu $16 \mathrm{TK}, 8 \mathrm{PK}, 7$ CK, 7 PCK, 7 TCK, 7 TPK dan 5 TPACK. Instrumen menggunakan 5 skala likert yang terdiri dari; 1) sangat tidak setuju; 2) tidak setuju; 3) ragu-ragu; 4) setuju; dan 5) sangat setuju. Semua butir instrument telah diuji validitasnya menggunakan Pearson Product Moment Correlation dengan hasil semuanya valid. Sementara reliabilitas dites menggunakan Cronbach's Alpha dengan hasil TK 0,884, PK 0,770, CK 0,703, PCK 0,827, TCK 0,858, TPK 0,802 dan TPACK 0,804.

Responden studi adalah mahasiswa semester 8 Prodi PPKn FKIP Universitas Pamulang yang baru saja selesai melakukan Praktik Pengalaman Lapangan (PPL). Terdapat 108 mahasiswa yang melakukan PPL pada semester genap 2017/2018. PPL dilakukan di Sekolah Menengah Pertama (SMP) dan Sekolah Menengah Atas (SMA) yang berada dalam wilayah Kota Tangerang Selatan selama 3 bulan, mulai Januari hingga Maret 2018.

Kuesioner diisi oleh mahasiswa secara online melalui aplikasi Google Form. Penyebarannya dilakukan dengan membagikan pranala kuesioner ke grup WhatsApp mahasiswa PPL yang sudah dibuat oleh pihak Prodi PPKn untuk memudahkan komunikasi dan penyampaian informasi terkait pelaksanaan dan pelaporan PPL. Penyebaran kuesioner dilakukan dengan sangat memperhatikan etika penelitian. Tidak ada instruksi dari pihak Prodi PPKn yang mewajibkan mahasiswa untuk mengisi kuesioner. Pengisian dilakukan secara sukarela oleh mahasiswa. Pada pengantar kuesioner dijelaskan bahwa data yang diberikan murni untuk kepentingan penelitian. Pengisian kuesioner tidak akan mempengaruhi nilai PPL dan dijamin kerahasiaan data pribadinya. 
Analisis terhadap data yang telah terkumpul dilakukan menggunakan teknik analisis data statistika deskriptif. Sebagai acuan analisis dan penafsiran data, maka dibuat skala rating dan predikatnya sebagai

\section{Hasil dan Pembahasan}

Setelah dilakukan penyebaran pranala kuesioner ke grup WA mahasiswa PPL Prodi PPKn, terdapat $78(72,22 \%)$ mahasiswa yang dengan sukarela mengisi kuesioner. Berikut berikut; 1) 1,00 - 1, 50 (sangat kurang); 2) 1,51 - 2,50 (kurang); 3) 2,51 - 3,50 (cukup); 4) 3,51 - 4,50 (baik); dan 5) 4,51 - 5,00 (sangat baik).

ini tersaji pada tabel di bawah ini Rincian Data Responden yang meliputi jenis kelamin, usia, status pernikahan, kursus IT dan pengalaman mengajar.

Tabel Data Responden

\begin{tabular}{|c|c|c|c|c|c|}
\hline \multicolumn{6}{|l|}{ Jenis Kelamin } \\
\hline \multirow{2}{*}{\multicolumn{2}{|c|}{$\begin{array}{l}\text { Laki-laki } \\
16(20,51 \%)\end{array}$}} & \multicolumn{4}{|c|}{ Perempuan } \\
\hline & & \multicolumn{4}{|c|}{$62(79,49 \%)$} \\
\hline \multicolumn{6}{|l|}{ Usia } \\
\hline$<20 \mathrm{Th}$ & $20-21 \mathrm{Th}$ & \multirow{2}{*}{\multicolumn{2}{|c|}{$\begin{array}{l}22-23 \mathrm{Th} \\
35(44.87 \%)\end{array}$}} & $24-25 \mathrm{Th}$ & $>25 \mathrm{Th}$ \\
\hline $1(1,28 \%)$ & $15(19,23 \%)$ & & & $5,38 \%)$ & $15(19,23 \%)$ \\
\hline \multicolumn{6}{|c|}{ Status Pernikahan } \\
\hline \multicolumn{2}{|l|}{ Belum Menikah } & \multicolumn{3}{|c|}{ Sudah Menikah } & \\
\hline \multicolumn{2}{|l|}{$57(73,08 \%)$} & \multicolumn{3}{|c|}{$21(26,92 \%)$} & \\
\hline \multicolumn{6}{|l|}{ Kursus IT } \\
\hline \multicolumn{2}{|l|}{ Tidak Pernah } & \multicolumn{3}{|l|}{ Pernah } & \\
\hline \multicolumn{2}{|l|}{$55(70,51 \%)$} & \multicolumn{3}{|c|}{$23(29,49 \%)$} & \\
\hline \multicolumn{6}{|c|}{ Pengalaman Mengajar } \\
\hline Belum & \multicolumn{5}{|c|}{ Sudah Berpengalaman } \\
\hline Berpengalaman & $<1 \mathrm{Th}$ & $1-2 \mathrm{Th}$ & $2-4 \mathrm{Th}$ & $5-6 \mathrm{Th}$ & $>6 \mathrm{Th}$ \\
\hline $48(61,54 \%)$ & $10(12,82 \%)$ & $11(14,10 \%)$ & $8(10,26 \%)$ & $0(0,00 \%)$ & $1(1,28 \%)$ \\
\hline
\end{tabular}

Sumber: Data Hasil Penelitian, 2018

Berdasarkan data di atas, didapati bahwa hampir $80 \%$ responden berjenis kelamin perempuan. Sebagian besar responden berusia antara 22 - 23 tahun $(44,87 \%)$, responden dengan usia 20 - 21 tahun dan 25 tahun ke atas memiliki jumlah yang sama yaitu 15 $(19.23 \%), 12(15,38 \%)$ responden berusia 24 - 25 tahun, dan hanya $1(1,28 \%)$ responden yang berusia di bawah 20 tahun. Lebih dari $70 \%$ responden belum menikah dan tidak pernah mengikuti kursus IT. Sedangkan, $60 \%$ lebih responden belum memiliki pengalaman mengajar, sementara yang sudah berpengalaman, hanya $1(1,28 \%)$ responden yang memiliki pengalaman mengajar lebih dari 5 tahun. Berdasarkan data pengalaman mengajar ini, menunjukkan bahwa terdapat hampir $40 \%$ mahasiswa PPKn yang menjadi responden penelitian ini, meskipun belum lulus kuliah namun sudah bekerja sebagai guru.
Studi mendapatkan data yang sangat menarik pada setiap domain TPACK. Data studi dideskripsikan dengan melihat nilai ratarata tertinggi dan terendah serta total rata-rata pada setiap domain pengetahuan. Lebih dari pada itu selanjutnya dilakukan analisis pada setiap butir pernyataan dengan membuat perbandingan dan korelasi yang relevan. Perhatian dipusatkan pada butir penyataan yang memiliki nilai rata-rata lebih rendah dari pada total nilai rata-rata pada setiap domain. Hal demikian dilakukan untuk mencari solusi dan merumuskan rekomendasi kepada semua pihak yang berkepentingan dalam mempersiapkan guru masa depan Indonesia. Berikut ini deskripsi nilai dan analisis pada masing-masing domain TPACK. Penjelasan terminologi pada setiap domain pengetahuan merupakan sintesis dari definisi yang sudah dirumuskan oleh Mishra \& Koehler (2008; 2009, 2013; 2006) 


\section{Technological Knowledge (TK)}

Technological knowledge atau pengetahuan teknologi adalah pengetahuan tentang berbagai perangkat teknologi baik yang analog maupun digital, lunak maupun keras, dan terkait hal teknis. Teknologi analog atau yang disebut juga dengan teknologi rendah meliputi buku, pensil, penggaris, papan tulis, dan kapur. Sedangkan teknologi digital meliputi internet, digital video, papan tulis interaktif, laptop, tablet, dan lainnya. Perangkat lunak komputer adalah seperti program pengolahan kata, kolom dan gambar, program penyaji presentasi dan berbagai aplikasi pada Internet. Sementara perangkat kerasnya, meliputi penggunaan printer, proyektor, scanner dan kamera digital. Hal teknis yang dimaksud meliputi kemampuan untuk menyelesaikan masalah yang terjadi pada perangkat teknologi yang digunakan, kemampuan untuk mempelajari teknologi baru serta kemampuan untuk menyimpan dan mengonversi file dalam berbagai format.

Nilai rata-rata tertinggi terdapat pada pengetahuan terkait bagaimana menggunakan aplikasi media sosial pada Internet $(4,49)$, sedangkan pengetahuan tentang berbagai perangkat keras komputer atau laptop beserta fungsinya merupakan yang terendah $(3,37)$. Secara keseluruhan, penguasaan pengetahuan teknologi pada calon guru PPKn termasuk dalam kategori baik (lihat tabel 1 pada lampiran). Namun meskipun termasuk dalam kategori baik apabila dilihat pada setiap butir pernyataan masih banyak yang mendapatkan nilai di bawah total nilai rata-rata. Pengetahuan teknologi calon guru PPKn masih lemah terkait dengan pengetahuan tentang berbagai perangkat lunak dan keras komputer beserta fungsinya, kemampuan untuk menyelesaikan masalah yang terjadi pada perangkat teknologi yang digunakan, kemampuan dalam menggunakan program pengolahan gambar dan kolom serta kemampuan dalam mengikuti perkembangan dan mempelajari teknologi baru.

\section{Pedagogical Knowledge (PK)}

Pedagogical

knowledge

atau

pengetahuan pedagogik adalah pengetahuan teoretis dan praktis tentang bagaimana cara belajar dan melaksanakan pembelajaran di kelas. Pengetahuan ini meliputi segala sesuatu yang berkaitan dengan perencanaan, proses, dan evaluasi pembelajaran. Lebih dari itu, pengetahuan pedagogik mencakup kemampuan untuk menyesuaikan pembelajaran sesuai dengan karakteristik, tingkat pemahaman dan kemungkinan kesalahpahaman atau misconception pada siswa.

Nilai rata-rata tertinggi terdapat pada pengetahuan tentang bagaimana merencanakan pembelajaran di kelas $(4,28)$, sedangkan yang terendah adalah kemampuan dalam mengetahui kesalahpahaman atau misconceptions pada siswa terhadap suatu konsep atau materi $(3,94)$. Secara keseluruhan penguasaan pengetahuan pedagogik pada calon guru PPKn termasuk dalam kategori baik (lihat tabel 2 pada lampiran). Meskipun termasuk dalam kategori baik, masih banyak juga butir penyataan pada pengetahuan pedagogik yang mendapatkan nilai di bawah total nilai rata-rata. Pengetahuan pedagogik calon guru PPKn masih lemah terkait dengan kemampuan mengelola kelas menggunakan berbagai strategi dan penilaian pembelajaran, serta menyesuaikan pembelajaran sesuai dengan karakteristik, tingkat pemahaman dan kemungkinan kesalahpahaman pada siswa.

\section{Content Knowledge (CK)}

Content knowledge atau pengetahuan konten adalah pengetahuan tentang materi yang harus dipelajari dan diajarkan beserta dengan karakteristiknya. Pengetahuan konten meliputi pengetahuan terhadap teori, konsep, fakta dan prosedur dalam bidang tertentu. Kemampuan untuk menggunakan cara berpikir sesuai dengan disiplin ilmu materi tertentu juga merupakan bagian dari pengetahuan konten. Dalam studi ini materinya adalah PPKn yang termasuk dalam bidang keilmuan sosial.

Nilai rata-rata tertinggi terdapat pada keaktifan dalam mengikuti seminar atau kegiatan sejenis yang bertema PPKn (4,31), sedangkan pengetahuan terhadap tokoh ilmuwan dalam bidang PPKn di Indonesia merupakan yang terendah $(3,54)$. Secara 
keseluruhan penguasaan pengetahuan konten pada calon guru PPKn termasuk dalam kategori baik (lihat tabel 3 pada lampiran). Namun masih terdapat tiga butir penyataan yang mendapatkan nilai di bawah total nilai rata-rata. Melihat pada butir pernyataan yang dimaksud ditemukan bahwa terkait pengetahuan konten calon guru PPKn masih lemah dalam mengikuti perkembangan keilmuan dan isu terbaru, mengetahui tokoh ilmuwan, dan perkembangan buku terbaru pada materi PPKn.

\section{Pedagogical Content Knowledge (PCK)}

Pedagogical content knowledge atau pengetahuan pedagogik konten adalah pengetahuan pedagogik yang berhubungan dengan konten yang spesifik. Pengetahuan ini merupakan perpaduan antara content knowledge dengan pedagogical knowledge yang pertama kali dikemukakan oleh Shulman (1986). Pengetahuan pedagogik konten berbeda pada berbagai konten karena masingmasing konten memiliki karakteristik sendiri untuk dapat cocok disampaikan dengan cara tertentu. Sederhananya pengetahuan ini merupakan pengetahuan tentang bagaimana cara belajar dan melaksanakan pembelajaran pada konten yang spesifik. Maksudnya adalah kecocokan model, pendekatan, strategi, metode, media, teknik dan taktik pembelajaran antara konten matematika dengan sejarah pasti sangat berbeda.

Nilai rata-rata tertinggi terdapat pada kemampuan dalam membuat sendiri Rencana Pelaksanaan Pembelajaran (RPP) pada mata pelajaran PPKn $(4,26)$. Pada sisi lain kemampuan dalam membuat keterkaitan antara materi mata pelajaran PPKn dengan materi mata pelajaran lain merupakan yang terendah $(3,91)$. Secara keseluruhan penguasaan pengetahuan pedagogik konten pada calon guru PPKn termasuk dalam kategori baik (lihat tabel 4 pada lampiran). Meskipun termasuk dalam kategori baik masih terdapat tiga butir penyataan yang mendapatkan nilai di bawah total nilai ratarata. Pengetahuan pedagogik konten calon guru PPKn masih lemah terkait kemampuan untuk membuat keterkaitan antara satu materi dengan materi yang lain pada mata pelajaran
PPKn dan dengan materi mata pelajaran lain, serta kemampuan dalam membuat materi yang susah dipahami menjadi mudah untuk dipahami oleh siswa.

\section{Technological Content Knowledge (TCK)}

Technological content knowledge atau pengetahuan teknologi konten adalah pengetahuan tentang bagaimana teknologi dan konten terkait secara timbal balik. Pengetahuan ini merupakan perpaduan antara technological knowledge dengan content knowledge. Pengetahuan ini berkaitan tentang bagaimana teknologi dapat membuat representasi baru pada konten yang spesifik. Termasuk dalam pengetahuan ini adalah mengetahui berbagai teknologi yang bisa digunakan untuk memudahkan dalam mempelajari, memahami, mengembangkan, dan mengekspresikan pemahaman pada konten yang spesifik. Pada studi ini konten spesifik yang dimaksud adalah materi PPKn.

Nilai rata-rata tertinggi terdapat pada penggunaan teknologi komunikasi seperti WhatsApp, BBM, Line dan lainnya untuk mendiskusikan materi PPKn dengan teman sejawat $(4,41)$. Sedangkan, penggunaan media sosial seperti Facebook, Twitter, Linked-in dan lainnya untuk terhubung dengan para tokoh ilmuwan PPKn di Indonesia merupakan yang terendah $(3,44)$. Secara keseluruhan penguasaan pengetahuan teknologi konten pada calon guru PPKn termasuk dalam kategori baik (lihat tabel 5 pada lampiran). Meskipun demikian seperti yang dapat dilihat pada tabel, masih terdapat tiga butir penyataan yang mendapatkan nilai di bawah total nilai rata-rata. Pengetahuan teknologi konten calon guru PPKn masih lemah pada berbagai teknologi yang bisa digunakan untuk mempelajari materi PPKn, penggunaan media sosial untuk memosting dan mengekspresikan pemahaman terhadap materi PPKn, serta penggunaan media sosial untuk terhubung dengan para tokoh ilmuwan PPKn di Indonesia.

\section{Technological Pedagogical Knowledge (TPK)}

Technological pedagogical knowledge atau pengetahuan teknologi pedagogik adalah pengetahuan tentang bagaimana berbagai 
teknologi dapat digunakan dalam belajar dan pembelajaran. Serta sebaliknya, pengetahuan ini berkaitan dengan bagaimana perencanaan, proses, evaluasi belajar, dan pembelajaran dapat berubah dengan adanya teknologi. Pengetahuan ini merupakan perpaduan antara technological knowledge dengan pedagogical knowledge. Termasuk dalam pengetahuan ini adalah kemampuan dalam memikirkan, memilih, dan menyesuaikan penggunaan teknologi untuk mempengaruhi dan meningkatkan strategi dan hasil pembelajaran.

Nilai rata-rata tertinggi terdapat pada kemampuan dalam memilih teknologi dan berpikir lebih dalam tentang fungsi teknologi yang dapat meningkatkan dan mempengaruhi penggunaan strategi pembelajaran di kelas merupakan pengetahuan teknologi pedagogik yang mendapatkan skor rata-rata tertinggi $(4,12)$. Sementara kemampuan dalam membantu guru lain untuk menggunakan teknologi dalam pembelajaran di kelas merupakan yang terendah $(3,81)$. Secara keseluruhan penguasaan pengetahuan teknologi pedagogik pada calon guru PPKn termasuk dalam kategori baik (lihat tabel 6 pada lampiran). Meskipun sudah baik, perhatian perlu dipusatkan pada dua butir pernyataan yang mendapatkan nilai di bawah total nilai rata-rata. Pengetahuan teknologi pedagogik calon guru PPKn masih lemah pada kemampuan dalam menyesuaikan penggunaan teknologi pada berbagai aktivitas pembelajaran dan membantu guru lain untuk menggunakan teknologi dalam pembelajaran di kelas.

\section{Technological Pedagogical Content Knowledge (TPACK)}

Technological Pedagogical Content Knowledge atau pengetahuan teknologi pedagogik konten adalah pengetahuan tentang bagaimana menggunakan teknologi yang tepat pada metode pedagogik yang sesuai untuk mengajarkan suatu konten yang spesifik dengan efektif. Pengetahuan ini merupakan perpaduan antara tiga pengetahuan dasar, yaitu content knowledge, pedagogical knowledge dan technological knowledge. Termasuk dalam pengetahuan ini adalah kemampuan dalam mengintegrasikan (memilih, menggunakan dan mengombinasikan) teknologi secara tepat pada strategi pembelajaran yang sesuai untuk mengajarkan konten yang spesifik. Puncak aktualisasi TPACK yaitu mampu membantu teman sejawat dalam menggunakan teknologi yang tepat pada strategi pembelajaran yang sesuai untuk mengajarkan konten yang spesifik dengan efektif di dalam kelas. Nilai rata-rata tertinggi terdapat pada kemampuan dalam menggunakan teknologi yang tepat pada strategi pembelajaran yang sesuai untuk menyampaikan materi PPKn dengan baik di dalam kelas $(4,03)$. Sedangkan, kemampuan dalam membantu guru lain untuk menggunakan teknologi yang tepat pada strategi pembelajaran yang sesuai dengan materi PPKn tertentu dalam pembelajaran di dalam kelas merupakan yang terendah $(3,63)$. Secara keseluruhan penguasaan pengetahuan teknologi pedagogik konten pada calon guru PPKn termasuk dalam kategori baik (lihat tabel 7 pada lampiran). Namun terdapat satu butir penyataan yang mendapatkan nilai yang cukup jauh di bawah total nilai rata-rata. Hal ini tentu harus diperhatikan, bahwa calon guru PPKn masih lemah terkait kemampuan dalam membantu guru lain untuk menggunakan teknologi yang tepat pada strategi pembelajaran yang sesuai dengan materi PPKn tertentu dalam pembelajaran di dalam kelas. Selanjutnya agar mendapatkan gambaran besarnya, berikut ini perbandingan total nilai rata-rata pada semua domain pengetahuan. 



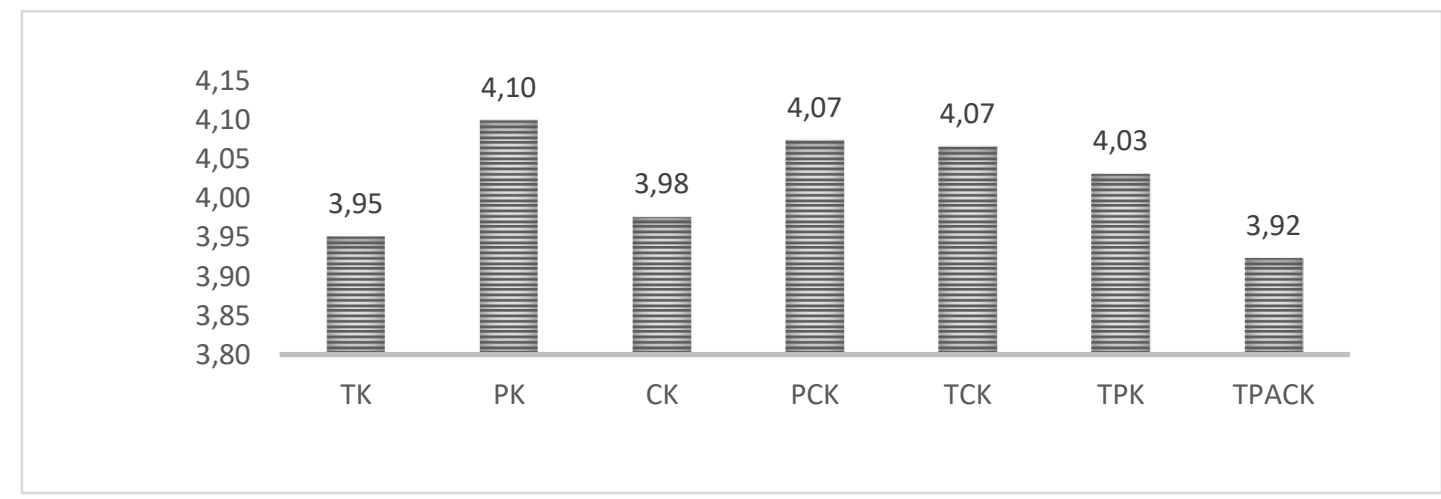

Grafik Perbandingan Total Nilai Rata-rata Semua Domain Pengetahuan

Sumber: Data Hasil Penelitian, 2018

Grafik di atas menunjukkan data tentang perbandingan total nilai rata-rata pada semua domain pengetahuan. Melalui gambar di atas ditemukan bahwa calon guru PPKn yang sedang menempuh pendidikan S1 di Prodi PPKn FKIP Universitas Pamulang memiliki total nilai rata-rata paling tinggi pada domain PK. Pada TCK dan PCK mendapatkan total nilai rata-rata yang sama dan masih tergolong cukup tinggi. Total nilai rata-rata TPK tidak jauh berbeda dengan dua pengetahuan sebelumnya. Total nilai rata-rata TK, CK dan TPACK lebih rendah dibandingkan dengan total nilai rata-rata pada domain pengetahuan lainnya.

Terindikasi terdapat hubungan hasil antar domain pengetahuan. Rendahnya pengetahuan teknologi dan konten, menjadikan para calon guru PPKn kurang bisa memainkan hubungan timbal balik antara teknologi dengan konten. Sehingga mereka kurang dapat memaksimalkan teknologi terkait dengan konten. Khususnya, pada pengetahuan pada berbagai teknologi yang bisa digunakan untuk mempelajari materi PPKn, penggunaan media sosial untuk memosting dan mengekspresikan pemahaman terhadap materi PPKn, dan penggunaan media sosial untuk terhubung dengan para tokoh ilmuwan PPKn di Indonesia. Rendahnya kedua pengetahuan tersebut berakibat pada rendahnya TPACK, khususnya terkait kemampuan dalam membantu guru lain untuk menggunakan teknologi yang tepat pada strategi pembelajaran yang sesuai dengan materi PPKn tertentu dalam pembelajaran di dalam kelas.
Sebagai calon guru, mengetahui berbagai teknologi itu penting, namun perlu disadari bahwa tidak semua teknologi diciptakan untuk tujuan pembelajaran. Maka, lebih daripada mengetahui teknologi, yang lebih penting adalah dapat berpikir kritis terhadap teknologi (Koehler et al., 2011) dengan mengetahui kapan dan mengapa harus menggunakan teknologi (Kereluik et al., 2013) dalam pembelajaran. Berikutnya, selain memiliki pengetahuan teknologi yang baik dalam rangka pengembangan TPACK harus didahului dengan penguasaan konten yang akan diajarkan dan cara mengajarkannya ini merupakan dasar untuk dapat mengintegrasikan teknologi dalam pembelajaran (Koehler et al., 2011). Singkatnya pengetahuan tentang konten atau materi yang akan diajarkan merupakan fondasi bagi guru untuk bisa mengajar dengan mengintegrasikan teknologi dalam pembelajaran dengan baik. Karakteristik konten menjadi pertimbangan awal dalam pemilihan strategi dan teknologi yang akan digunakan untuk melaksanakan pembelajaran.

Hasil penelitian ini memperlihatkan berbagai kebutuhan pengembangan TPACK pada calon guru PPKn. Pengembangan TPACK bagi calon guru PPKn hendaknya dimulai dengan mematangkan pengetahuan konten terlebih dulu, lalu kemudian meningkatkan pengetahuan teknologi. Pematangan terhadap konten PPKn lebih ditekankan pada pengetahuan terhadap perkembangan keilmuan dan isu terbaru, tokoh ilmuwan bidang PPKn, dan perkembangan buku terbaru pada materi PPKn. Materi PPKn cukup dinamis dan selalu 
mengalami perkembangan sesuai dengan fenomena yang terjadi di masyarakat maka secara keilmuan dan pengetahuan terhadap isu yang berkaitan dengan PPKn perlu terus diikuti kebaruannya oleh calon guru PPKn masa depan. Sejalan dengan hal tersebut familieritas calon guru PPKn terhadap tokoh ilmuwan dan buku baru dalam bidang PPKn perlu ditingkatkan agar dapat mengikuti perkembangan keilmuan dan isu terbaru secara berkelanjutan.

Sangat disayangkan permasalahan dalam penguasaan pengetahuan teknologi pada calon guru PPKn masih berkaitan dengan hal teknis. Seharusnya pengetahuan teknis terkait berbagai perangkat lunak dan keras teknologi komputer sudah dikuasai sebelum menempuh pendidikan calon guru di perguruan tinggi. Hal ini memperlihatkan bahwa calon guru PPKn masih memiliki masalah pada literasi digital yang rendah. Fenomena ini memunculkan pemikiran untuk lebih selektif lagi dalam menerima mahasiswa calon guru dengan mempertimbangkan kemampuan teknologi yang dimiliki sebagai salah satu komponen seleksi. Pada tingkat perguruan tinggi terutama pada program pendidikan calon guru seharusnya pendidikan terkait teknologi sudah lebih daripada mengajarkan teknis penggunaan teknologi. Pendidikan terkait teknologi sudah harus berada pada level penggunaan teknologi yang tepat pada metode pedagogik yang sesuai untuk mengajarkan suatu konten yang spesifik dengan efektif dan efisien.

Pengetahuan yang sudah dikuasai dengan baik pada calon guru PPKn perlu untuk dipertahankan dan terus ditingkatkan. Pengetahuan pedagogik calon guru PPKn memang memiliki total nilai rata-rata paling tinggi di antara semua domain pengetahuan TPACK. Namun secara lebih terperinci para guru masih perlu ditingkatkan dalam hal pengelolaan kelas, penggunaan strategi dan penilaian pembelajaran, penyesuaian pembelajaran dengan karakteristik siswa, dan mengatasi kesalahpahaman atau misconception pada siswa karena nilai ratarata pada beberapa hal tersebut mendapatkan nilai di bawah total nilai rata-rata. Pengetahuan pedagogik yang sudah baik seperti pengetahuan tentang perencanaan dan prosedur umum pelaksanaan pembelajaran harus dipertahankan dan terus ditingkatkan supaya calon guru PPKn dapat melaksanakan pembelajaran dengan baik sesuai dengan prosedur.

Terkait dengan domain pengetahuan lainnya yang merupakan gabungan dari ketiga pengetahuan dasar, terdapat beberapa hal yang perlu ditingkatkan. Pada pengetahuan pedagogik konten calon guru PPKn, perlu ditingkatkan terkait kemampuan untuk membuat keterkaitan antara satu materi dengan materi yang lain pada mata pelajaran PPKn dan dengan materi mata pelajaran lain serta kemampuan dalam membuat materi yang sulit dipahami menjadi mudah untuk dipahami oleh siswa. Pada pengetahuan teknologi konten calon guru PPKn perlu ditingkatkan pada kemampuan dalam menggunakan berbagai teknologi yang bisa digunakan untuk mempelajari materi PPKn, penggunaan media sosial untuk memosting dan mengekspresikan pemahaman terhadap materi PPKn, serta penggunaan media sosial untuk terhubung dengan para tokoh ilmuwan PPKn di Indonesia. Pada pengetahuan teknologi pedagogik calon guru PPKn perlu ditingkatkan pada kemampuan dalam menyesuaikan penggunaan teknologi pada berbagai aktivitas pembelajaran dan membantu guru lain untuk menggunakan teknologi dalam pembelajaran di kelas.

Pada akhirnya, hasil penelitian dan pembahasan ini harus menjadi perhatian dan suatu refleksi bagi Prodi PPKn FKIP Universitas Pamulang dan umumnya bagi lembaga penyelenggara pendidikan calon guru PPKn lainnya. Perhatian khususnya ditujukan pada berbagai kemampuan dalam domain pengetahuan tertentu yang masih perlu untuk ditingkatkan dan pada kemampuan lain yang sudah baik untuk tetap dipertahankan dan terus ditingkatkan. Hasil penelitian ini merefleksikan kualitas dan mutu calon guru PPKn yang dapat dijadikan sebagai bahan pertimbangan untuk pengambilan keputusan dalam rangka perbaikan program pendidikan guru PPKn yang lebih sesuai dengan tuntutan dan karakteristik pembelajaran abad 21. Perbaikan terhadap 
program pendidikan guru perlu terus dilakukan karena kualitas guru ditentukan pada saat pendidikan guru dilakukan Swennen \& Klink (2009), maka, analisis dan rekomendasi dalam studi ini sudah sepatutnya untuk dapat dipertimbangkan dalam rangka mempersiapkan guru masa depan yang lebih baik.

\section{Simpulan}

Secara keseluruhan tingkat penguasaan TPACK calon guru PPKn yang sedang menempuh pendidikan S1 di Prodi PPKn FKIP Universitas Pamulang termasuk dalam kategori baik. Namun, penguasaan khususnya pada TK, CK dan TPACK, masih perlu ditingkatkan supaya calon guru PPKn dapat mengintegrasikan teknologi dan membantu teman sejawat terkait integrasi teknologi dalam pembelajaran. Selain itu, perlu diperhatikan pada setiap butir pernyataan yang memiliki nilai rata-rata lebih rendah daripada nilai total rata-rata pada setiap domain pengetahuan. Studi ini terbatas pada satu prodi dalam satu LPTK. Setiap LPTK perlu melakukan sebuah analisis TPACK untuk mengetahui apakah calon guru yang sedang dididik sudah memiliki berbagai jenis pengetahuan yang dibutuhkan guru untuk dapat mengajar sesuai dengan tuntutan dan karakteristik pembelajaran abad 21. Selain analisis terhadap penguasaan TPACK calon guru, LPTK perlu meninjau kembali kurikulum pendidikan gurunya untuk melihat apakah sudah sesuai dengan tuntutan dan karakteristik pembelajaran abad 21. Jika belum, TPACK framework dapat dijadikan sebagai kerangka kerja untuk mengembangkan kurikulum pendidikan guru baru yang lebih relevan dengan tuntutan dan karakteristik pembelajaran abad 21 .

\section{Referensi}

Abbitt, J. T. (2011). Measuring technological pedagogical content knowledge in preservice teacher education: A review of current methods and instruments. Journal of Research on Technology in Education, 43(4),

281-300. https://doi.org/10.1080/15391523.2011.1 0782573
Agustina, P., Putri, P., Sundari, K., \& Ardani, D. E. (2016). Kemampuan mahasiswa calon guru Biologi dalam merancang pembelajaran berbasis praktikum: studi kasus mahasiswa pendidikan Biologi FKIP UMS. In Prosiding Biology Education Conference (Vol. 13, hal. 536540).

Agustina, P., Yusron, F. N., \& Muyassarah, F. (2018). Pedagogical content knowledge (PCK) mahasiswa calon guru biologi FKIP UMS pada matakuliah microteaching tahun akademik 2015/2016. In The 7th University Research Colloqium (hal. 101-108).

Baser, D., Kopcha, T. J., \& Ozden, M. Y. (2016). Developing a technological pedagogical content knowledge (TPACK) assessment for preservice teachers learning to teach English as a foreign language. Computer Assisted Language Learning, 29(4), 749-764.

Canbazoglu Bilici, S., Guzey, S. S., \& Yamak, H. (2016). Assessing pre-service science teachers' technological pedagogical content knowledge (TPACK) through observations and lesson plans. Research in Science and Technological Education, 34(2), 237-251. https://doi.org/10.1080/02635143.2016.1 144050

Celik, B. (2017). Teaching profession and passion. International Journal of Social Sciences and Educational Studies, $4(2$ (Special Issue)), 85-92. https://doi.org/10.23918/ijsses.v4i2sip85

Chai, C. S., Koh, J. H. L., \& Tsai, C.-C. (2016). 6A Review of the quantitative measures of Technological Pedagogical Content Knowledge (TPACK). In Handbook of technological pedagogical content knowledge (TPACK) for educators (hal. 97-116). Routledge.

Cox, S., \& Graham, C. R. (2009). Using an elaborated model of the TPACK framework to analyzed and depict teacher knowledge. TechTrends, 53(5), 60-69. https://doi.org/10.1103/PhysRevLett.59. 435

Cuhadar, C. (2018). Investigation of preservice teachers' levels of readiness to 
technology integration in education. Contemporary Educational Technology, 9(1), 61-75.

Dhawati, D. A. A., \& Hariyatmi. (2017). Kemampuan Technological Knowledge (TK) calon guru Biologi FKIP UMS. In Prosiding SNPBS (Seminar Nasional Pendidikan Biologi dan Saintek) Ke-2 (hal. 649-654).

Haider, A., \& Jalal, S. (2018). Good teacher and teaching through the lens of students. International Journal of Research, 5(7), 1395-1409.

Jang, S.-J., \& Tsai, M.-F. (2012). Exploring the TPACK of Taiwanese elementary mathematics and science teachers with respect to use of interactive whiteboards. Computers \& Education, 59(2), 327-338.

Kereluik, K., Mishra, P., Fahnoe, C., \& Terry, L. (2013). What Knowledge Is of Most Worth: Teacher Knowledge for $21 \mathrm{st}$ Century Learning. Journal of Digital Learning in Teacher Education, 29(4), 127-140.

https://doi.org/10.1080/21532974.2013.1 0784716

Koehler, M. J., \& Mishra, P. (2008). Introducing TPCK. AACTE Committee on Innovation and Technology. In The handbook of technological pedagogical content knowledge (TPCK) for educators (hal. 3-29). Mahwah, NJ: Lawrence Erlbaum Associates.

Koehler, M. J., Mishra, P., Bouck, E. C., DeSchryver, M., Kereluik, K., Shin, T. S., \& Wolf, L. G. (2011). Deep-play: developing TPACK for 21 st century teachers. International Journal of Learning Technology, 6(2), 146. https://doi.org/10.1504/ijlt.2011.042646

Koehler, M. J., Mishra, P., \& Cain, W. (2009). What is Technological Pedagogical Content Knowledge (TPACK)? Contemporary Issues in Technology and Teacher Education, 9(1), 60=70. https://doi.org/10.1177/00220574131930 0303

Koehler, M. J., Mishra, P., \& Cain, W. (2013). What Is Technological Pedagogical Content Knowledge ( TPACK )? Journal of Education, 193(3), 13-19.
Koehler, M. J., Shin, T. S., \& Mishra, P. (2012). How do we measure TPACK? let me count the ways. In Ro. N. Ronau, C. R. Rakes, \& M. L. Niess (Ed.), Educational technology, teacher knowledge, and classroom impact: a research handbook on frameworks and approaches. Hershey PA: IGI Global.

Listiawan, T., \& Baskoro, W. W. (2015). Analisis Technological Content Knowledge ( TCK ) calon guru Matematika dalam menggunakan perangkat lunak geometri dinamis. In Seminar Nasional Matematika dan Pendidikan Matematika (hal. 827-834). Yogyakarta. https://doi.org/10.13140/RG.2.1.4443.35 22

Maeng, J. L., Mulvey, B. K., Smetana, L. K., \& Bell, R. L. (2013). Preservice teachers' TPACK: using technology to iupport inquiry instruction. Journal of Science Education and Technology, 22(6), 838857. https://doi.org/10.1007/s10956-0139434-z

Meijer, P. C., Korthagen, F. A. J., \& Vasalos, A. (2009). Supporting presence in teacher education: The connection between the personal and professional aspects of teaching. Teaching and Teacher Education, 25(2), 297-308. https://doi.org/10.1016/j.tate.2008.09.01 3

Mishra, P., \& Koehler, M. J. (2006). Technological pedagogical content knowledge: a framework for integrating technology in teacher knowledge. Teachers College Record, 108(6), 10171054.

Mouza, C. (2016). Developing and assessing TPACK among pre-service teachers. In Handbook of technological pedagogical content knowledge (TPACK) for educators (Vol. 169). Routledge New York, NY.

Partnership for 21st Century Learning. (2015). P21 partnership for 21st century learning. Partnership for 21st Century Learning. Diambil dari http://www.p21.org/documents/P21_Fra mework_Definitions.pdf 
Raman, A. (2014). TPACK confidence of preservice teachers in Universiti Utara Malaysia. Mediterranean Journal of Social Sciences, 5(22), 167-175. https://doi.org/10.5901/mjss.2014.v5n22 p167

Sahin, I. (2011). Development of survey of technological pedagogical and content knowledge (TPACK). Turkish Online Journal of Educational Technology, 10(1), 97-105.

Sakuma, A. (2018). The origin of teaching as a profession in Japan: A transnational analysis of the relationship between professionalism and nationalism in the 19 th century. Espacio, Tiempo y Educacion, $5(2)$, $35-54$. https://doi.org/10.14516/ete.232

Schmidt, D. A., Thompson, A. D., Koehler, M. J., \& Shin, T. S. (2009). Technological Pedagogical Content Knowledge (TPACK): the development and validation of an assessment instrument for preservice teachers. Journal of Research on Technology in Education, 42(2), 123-149.

Sholihah, M., Yuliati, L., \& Wartono. (2016). Peranan TPACK terhadap kemampuan calon guru Fisika dalam pembelajaran post-pack. Jurnal Pendidikan: Teori, penelitian, dan Pengembangan, 1(2), 144-153.

Shulman, L. S. (1986). Thoe who understan: knowledge growth in teaching. Educational Researcher, 15(2), 4-14.

Srinivasan, M., Li, S. T. T., Meyers, F. J., Pratt, D. D., Collins, J. B., Braddock, C., ... Hilty, D. M. (2011). "Teaching as a competency": Competencies for medical educators. Academic Medicine, 86(10), 1211-1220.

https://doi.org/10.1097/ACM.0b013e318 $22 \mathrm{c} 5 \mathrm{~b} 9 \mathrm{a}$

Sukaesih, S., Ridlo, S., \& Saptono, S. (2017). Analisis kemampuan Technological Pedagogical and Content Knowledge (TPACK) calon guru pada mata kuliah PP BIO. In Prosiding SNPS (Seminar Nasional Pendidikan Sains) (hal. 58-64).
Swennen, A., \& Klink, M. van der. (2009). Epilogue: enhancing the profession of teacher educators. In Becoming a Teacher Educator (hal. 219-226). Springer.

Walsh, A., Koppula, S., Antao, V., Bethune, C., Cameron, S., Cavett, T., ... Dove, M. (2018). Preparing teachers for competency-based medical education: Fundamental teaching activities. Medical Teacher, 40(1), 80-85. https://doi.org/10.1080/0142159X.2017. 1394998 


\section{Lampiran}

Tabel 1. Nilai Rata-rata TK

\begin{tabular}{|c|c|c|c|}
\hline No. & Pernyataan & $\begin{array}{c}\text { Rata- } \\
\text { rata }\end{array}$ & Ket. \\
\hline 1. & $\begin{array}{l}\text { Saya tahu bagaimana mengatasi masalah teknis yang terjadi pada komputer/laptop } \\
\text { milik saya sendiri }\end{array}$ & 3,64 & Baik \\
\hline 2. & Saya bisa mempelajari berbagai teknologi dengan mudah & 3,72 & Baik \\
\hline 3. & Saya mengikuti perkembangan teknologi baru yang penting untuk saya & 3,88 & Baik \\
\hline 4. & Saya sering mengutak-atik perangkat teknologi untuk mencari tahu lebih lanjut & 3,79 & Baik \\
\hline 5. & Saya tahu berbagai jenis teknologi komputer/laptop yang berbeda-beda & 3,47 & Cukup \\
\hline 6. & $\begin{array}{l}\text { Saya tahu berbagai perangkat keras komputer/laptop (contoh: mother-board, } \\
\text { RAM) dan fungsinya }\end{array}$ & 3,37 & Cukup \\
\hline 7. & $\begin{array}{l}\text { Saya tahu berbagai perangkat lunak komputer/laptop (contoh: Windows, Media } \\
\text { Player) dan fungsinya }\end{array}$ & 3,83 & Baik \\
\hline 8. & $\begin{array}{l}\text { Saya tahu bagaimana menggunakan program pengolahan kata (contoh: Microsoft } \\
\text { Word) }\end{array}$ & 4,32 & Baik \\
\hline 9. & $\begin{array}{l}\text { Saya tahu bagaimana menggunakan program pengolahan kolom (contoh: } \\
\text { Microsoft Excel) }\end{array}$ & 3,94 & Baik \\
\hline 10. & $\begin{array}{l}\text { Saya tahu bagaimana menggunakan program penyajian presentasi (contoh: } \\
\text { Microsoft PowerPoint) }\end{array}$ & 4,37 & Baik \\
\hline 11. & $\begin{array}{l}\text { Saya tahu bagaimana menggunakan program pengolahan gambar (contoh: Adobe } \\
\text { Photoshop) }\end{array}$ & 3,38 & Cukup \\
\hline 12. & $\begin{array}{l}\text { Saya tahu bagaimana menggunakan aplikasi komunikasi pada internet (contoh: } \\
\text { Email) }\end{array}$ & 4,47 & Baik \\
\hline 13. & $\begin{array}{l}\text { Saya tahu bagaimana menggunakan aplikasi media sosial pada internet (contoh: } \\
\text { Facebook, Instagram) }\end{array}$ & 4,49 & Baik \\
\hline 14. & Saya bisa menyimpan data dalam bentuk digital (contoh: CD, DVD, Flash Disk) & 4,37 & Baik \\
\hline 15. & $\begin{array}{l}\text { Saya bisa menyimpan dan mengubah data dalam berbagai format (contoh: } \\
\text { mengubah file MS.Word ke PDF) }\end{array}$ & 4,05 & Baik \\
\hline 16. & Saya bisa menggunakan printer, proyektor, scanner, dan kamera digital. & 4,10 & Baik \\
\hline \multicolumn{2}{|c|}{ Total } & 3,95 & Baik \\
\hline
\end{tabular}

Tabel 2. Nilai Rata-rata PK

\begin{tabular}{clcc}
\hline No. & Pernyataan & $\begin{array}{c}\text { Rata- } \\
\text { rata }\end{array}$ & Ket. \\
\hline 1. & Saya tahu bagaimana merencanakan pembelajaran di kelas & 4,28 & Baik \\
2. & Saya tahu bagaimana prosedur umum pelaksanaan pembelajaran di kelas & 4,26 & Baik \\
3. & Saya tahu bagaimana mengatur dan mengelola kelas & 4,09 & Baik \\
4. & $\begin{array}{l}\text { Saya bisa menyesuaikan gaya mengajar saya pada siswa yang memiliki karakter } \\
\quad \text { yang berbeda }\end{array}$ & 4,12 & Baik \\
5. $\quad \begin{array}{l}\text { Saya bisa menyesuaikan proses pembelajaran saya berdasarkan apa yang siswa } \\
\text { sudah mengerti dan belum mengerti }\end{array}$ & 4,03 & Baik \\
6. $\quad \begin{array}{l}\text { Saya bisa menggunakan berbagai model, pendekatan, strategi, metode, media, } \\
\text { teknik, dan taktik pembelajaran di kelas }\end{array}$ & 4,08 & Baik \\
7. & $\begin{array}{l}\text { Saya bisa mengetahui kesalahpahaman (misconceptions) siswa terhadap suatu } \\
\text { konsep atau materi }\end{array}$ & 3,94 & Baik \\
8. & Saya bisa menilai pembelajaran siswa menggunakan berbagai jenis penilaian & 4,01 & Baik \\
\hline Total & 4,10 & Baik \\
\hline
\end{tabular}


Tabel 3. Nilai Rata-rata CK

\begin{tabular}{clcc}
\hline No. & Pernyataan & $\begin{array}{c}\text { Rata- } \\
\text { rata }\end{array}$ & Ket. \\
\hline 1. & Saya memiliki pengetahuan yang baik terhadap materi Pendidikan Pancasila dan & 3,99 & Baik \\
& Kewarganegaraan (PPKn) & & \\
2. & Saya memiliki berbagai cara dan strategi untuk mengembangkan pemahaman saya & 4,10 & Baik \\
& terhadap materi PPKn & 4,09 & Baik \\
3. & Saya bisa menggunakan cara berpikir ilmu sosial & 3,97 & Baik \\
4. & Saya mengikuti perkembangan keilmuan dan isu terbaru dalam bidang PPKn & 3,54 & Cukup \\
5. & Saya mengetahui tokoh ilmuwan bidang PPKn di Indonesia & 3,83 & Baik \\
6. & Saya mengikuti perkembangan buku terbaru pada materi PPKn & 4,31 & Baik \\
7. & Saya mengikuti seminar atau kegiatan sejenis yang bertema PPKn & 3,98 & Baik \\
\hline \multicolumn{2}{l}{ Total } & & \\
\hline
\end{tabular}

Tabel 4. Nilai Rata-rata PCK

\begin{tabular}{clcc}
\hline No. & Pernyataan & $\begin{array}{c}\text { Rata- } \\
\text { rata }\end{array}$ & Ket. \\
\hline 1. & $\begin{array}{l}\text { Saya bisa membuat sendiri Rencana Pelaksanaan Pembelajaran (RPP) pada mata } \\
\text { pelajaran Pendidikan Pancasila dan Kewarganegaraan (PPKn) }\end{array}$ & 4,26 & Baik \\
2. & $\begin{array}{l}\text { Saya bisa memilih model, pendekatan, strategi, metode, media, teknik, dan taktik } \\
\text { pembelajaran yang sesuai dengan materi PPKn }\end{array}$ & 4,13 & Baik \\
3. $\quad \begin{array}{l}\text { Saya bisa membuat materi PPKn yang susah dipahami menjadi mudah untuk dapat } \\
\text { dipahami oleh siswa }\end{array}$ & 3,94 & Baik \\
& $\begin{array}{l}\text { Saya bisa membuat keterkaitan antara satu materi dengan materi yang lain pada } \\
\text { mata pelajaran PPKn }\end{array}$ & 3,92 & Baik \\
5. $\quad \begin{array}{l}\text { Saya bisa membuat keterkaitan antara materi mata pelajaran PPKn dengan materi } \\
\text { mata pelajaran lain }\end{array}$ & 3,91 & Baik \\
6. & Saya bisa menggunakan berbagai sumber belajar untuk mengajarkan materi PPKn \\
7. & Saya bisa membuat sendiri kisi-kisi dan soal tes pada mata pelajaran PPKn & 4,18 & Baik \\
\hline Total & 4,18 & Baik \\
\hline
\end{tabular}

Tabel 5. Nilai Rata-rata TCK

\begin{tabular}{clcc}
\hline No. & Pernyataan & $\begin{array}{c}\text { Rata- } \\
\text { rata }\end{array}$ & Ket. \\
\hline 1. & $\begin{array}{l}\text { Saya tahu berbagai teknologi yang bisa saya gunakan untuk mempelajari materi } \\
\text { Pendidikan Pancasila dan Kewarganegaraan (PPKn) }\end{array}$ & 4,03 & Baik \\
2. $\quad \begin{array}{l}\text { Saya bisa menggunakan aplikasi komputer/laptop tertentu untuk memudahkan } \\
\text { saya memahami materi PPKn }\end{array}$ & 4,17 & Baik \\
3. $\quad \begin{array}{l}\text { Saya bisa menggunakan komputer/laptop dengan baik untuk mengembangkan } \\
\text { (menyusun makalah dan membuat slide presentasi) materi PPKn }\end{array}$ & 4,31 & Baik \\
4. $\quad \begin{array}{l}\text { Saya menggunakan teknologi berupa internet sebagai sumber belajar untuk } \\
\text { mencari materi PPKn }\end{array}$ & 4,40 & Baik \\
5. $\quad \begin{array}{l}\text { Saya menggunakan teknologi komunikasi seperti WhatsApp, BBM, Line, dan } \\
\text { lainnya untuk mendiskusikan materi PPKn dengan teman sejawat }\end{array}$ & 4,41 & Baik \\
$\quad \begin{array}{l}\text { Saya menggunakan media sosial seperti Facebook, Instagram, twitter, blog, dan } \\
\text { lainnya untuk memosting dan mengekspresikan pemahaman saya terhadap materi }\end{array}$ & 3,72 & Baik \\
$\quad \begin{array}{l}\text { PPKn } \\
\text { Saya menggunakan media sosial seperti Facebook, Twitter, Linked-in, dan lainnya } \\
\text { untuk terhubung dengan para tokoh ilmuwan PPKn di Indonesia }\end{array}$ & 3,44 & Cukup \\
\hline Total & 4,07 & Baik \\
\hline
\end{tabular}


Tabel 6. Nilai Rata-rata TPK

\begin{tabular}{|c|c|c|c|}
\hline No. & Pernyataan & $\begin{array}{c}\text { Rata- } \\
\text { rata }\end{array}$ & Ket. \\
\hline 1. & $\begin{array}{l}\text { Saya bisa memilih teknologi yang dapat meningkatkan strategi pembelajaran di } \\
\text { kelas }\end{array}$ & 4,12 & Baik \\
\hline 2. & $\begin{array}{l}\text { Saya berpikir lebih dalam tentang bagaimana teknologi dapat mempengaruhi } \\
\text { strategi pembelajaran yang saya gunakan di kelas }\end{array}$ & 4,12 & Baik \\
\hline 3. & $\begin{array}{l}\text { Saya bisa memilih teknologi yang dapat meningkatkan daya tarik siswa selama } \\
\text { proses pembelajaran di kelas }\end{array}$ & 4,10 & Baik \\
\hline 4. & $\begin{array}{l}\text { Saya berpikir kritis tentang bagaimana menggunakan teknologi dalam } \\
\text { pembelajaran di kelas }\end{array}$ & 4,06 & Baik \\
\hline 5. & $\begin{array}{l}\text { Saya bisa menyesuaikan penggunaan teknologi pada berbagai aktivitas } \\
\text { pembelajaran di kelas }\end{array}$ & 3,97 & Baik \\
\hline 6. & $\begin{array}{l}\text { Saya bisa memilih teknologi yang dapat digunakan untuk meningkatkan hasil } \\
\text { pembelajaran di kelas }\end{array}$ & 4,04 & Baik \\
\hline 7. & $\begin{array}{l}\text { Saya bisa membantu guru lain untuk menggunakan teknologi dalam pembelajaran } \\
\text { di kelas }\end{array}$ & 3,81 & Baik \\
\hline Total & & 4,03 & Baik \\
\hline
\end{tabular}

Tabel 7. Nilai Rata-rata TPACK

\begin{tabular}{|c|c|c|c|}
\hline No. & Pernyataan & $\begin{array}{c}\text { Rata- } \\
\text { rata }\end{array}$ & Ket. \\
\hline 1. & $\begin{array}{l}\text { Saya bisa menggunakan teknologi yang tepat pada strategi pembelajaran yang } \\
\text { sesuai untuk menyampaikan materi Pendidikan Pancasila dan Kewarganegaraan } \\
(\mathrm{PPKn}) \text { dengan efektif di dalam kelas }\end{array}$ & 4,03 & Baik \\
\hline 2. & $\begin{array}{l}\text { Saya bisa memilih teknologi yang tepat untuk meningkatkan pemahaman siswa } \\
\text { terhadap materi PPKn yang saya ajarkan menggunakan strategi pembelajaran } \\
\text { tertentu di dalam kelas }\end{array}$ & 4,00 & Baik \\
\hline 3. & $\begin{array}{l}\text { Saya bisa memilih teknologi yang tepat untuk melakukan penilaian hasil belajar } \\
\text { siswa pada mata pelajaran PPKn yang saya ajarkan menggunakan strategi } \\
\text { pembelajaran tertentu di dalam kelas }\end{array}$ & 3,95 & Baik \\
\hline 4. & $\begin{array}{l}\text { Saya bisa melaksanakan pembelajaran yang baik dengan mengombinasikan } \\
\text { penggunaan teknologi yang tepat dan strategi pembelajaran yang sesuai pada mata } \\
\text { pelajaran PPKn di dalam kelas }\end{array}$ & 4,01 & Baik \\
\hline 5. & $\begin{array}{l}\text { Saya bisa membantu guru lain untuk menggunakan teknologi yang tepat pada } \\
\text { strategi pembelajaran yang sesuai dengan materi PPKn tertentu dalam } \\
\text { pembelajaran di dalam kelas }\end{array}$ & 3,63 & Baik \\
\hline Total & & 3,92 & Baik \\
\hline
\end{tabular}

